\title{
Factors Contributing to the Entrepreneurial Development in Bangladesh: A Study on Rajshahi City
}

\author{
A.N.M. Jahangir Kabir \\ Professor, Department of Management Studies, University of Rajshahi, Bangladesh-6205, BANGLADESH \\ *E-mail for correspondence: anmjk@ru.ac.bd
}

https://doi.org/10.18034/abr.v8i2.149

\begin{abstract}
This paper attempts to examine the impact of pull and push factors on the entrepreneurial development process. The pull factor "earning extra money for family" has appeared as the most important motivating factor for undertaking an entrepreneurial activity. Both the factors such as "selfemployment with economic freedom" and "Less complex and more profitable" have emerged as the second most important factors contributing to an entrepreneurial phenomenon, followed by the factor "Use of personal knowledge and experience" being the third most important factor. The support from the government and the financial support from the bank have been found to be little to do with the respondents' undertaking the entrepreneurial activity.

The respondents with experience of '10 years and above' have ranked the factors 'Less complex and more profitable' and 'Earning extra money for family' as the most important and second most important motivating factors respectively. Whereas the respondents without any experience and with experience below ten years have ranked the factors 'Earning extra money for family' and 'Selfemployment with economic freedom' in the first or second place contrariwise. Irrespective of the nature of businesses they are engaged in, all the respondents have viewed the factor 'Curse of unemployment' as the most important factor that compelled them to undertake the entrepreneurial activity.
\end{abstract}

Key words: Entrepreneur, Self-employment, Pull factors, Push factors, Socio-economic factors

\section{INTRODUCTION}

The existence of entrepreneurs in an economy along with the presence of a conducive milieu contained with psychological (internal factors: human value and motives) (Mishra, 1990), cultural values (Cochran, 1965), social structure (Stocks, 1974), political, organizational and economic situations can help propel an economy of a country.

Richard Cantillon (1697-1734) was the earliest scientist who paid considerable attention to the entrepreneur. He introduced the very concept of 'entrepreneur (Praag, 1999). He was the first to acknowledge that there is an entrepreneurial function within the economic system. He added that the entrepreneur is functionally described as an arbitrageur. By engaging in arbitrage and bearing risk, the entrepreneurial class has an equilibrating function within an economic system.
Various theories have evolved in a bit to ease the understanding of the possible scenarios that give rise to entrepreneurial phenomena. Entrepreneurial activity gets a boost when a society has a sufficient supply of individuals with necessary psychological characteristics. Achievement theory stresses that people oriented with high achievement are likely to involve in entrepreneurial activity. Alfred Marshall's theory of entrepreneurship considered entrepreneurial phenomenon as the driving force bringing together the four factors of production such as land, labor, capital, and organization. The sociological theory of entrepreneurship holds the social culture as the driving force causing entrepreneurial events to take place. The innovation theory of entrepreneurship considers an entrepreneur to have three characteristics such as innovation, foresight, and creativity. Israel Kirzner's theory of entrepreneurship considers an entrepreneurial phenomenon as the alertness or awareness on the part of an individual to recognize an economic opportunity in the 
face of uncertainty. Leibenstein's theory of entrepreneurship considers an entrepreneur both as a gap-filler and an input completer. All these theories cited so far present some sporadic concepts of contextual arrangements in which entrepreneurial phenomenon can take place. However, an integrated contextual model (Mahmud, 1980) attempts to explain that some factors that are sociological and psychological take a sufficiently long time to change, whereas others like economic, political and legal are quickly manipulable to render an environment conducive to the emergence of entrepreneurial phenomena. Each of the theories related to entrepreneurship attempts to view the entrepreneurial phenomenon based on the respective disciplines they belong to. The various factors that cause the entrepreneurial activity to take place are integral not additive (Sharma, 1980). The phenomenon being the resultant outcome of the interlocking interplay of multi-dimensional variables, no single discipline can provide a conceptual purview explaining the reasons for taking place an entrepreneurial activity. Amidst such floundering situation to find out a clear idea about the conditions that cause an entrepreneurial event to take place, an attempt has been made to explain conditions contributing to the entrepreneurial trend (Srivastava, 1989).

Conditions influencing entrepreneurial trend

\begin{tabular}{|c|c|c|c|c|}
\hline $\begin{array}{l}\text { Social } \\
\text { conditions }\end{array}$ & + & $\begin{array}{l}\text { Economic } \\
\text { conditions }\end{array}$ & $=$ & $\begin{array}{l}\text { Entrepreneurial } \\
\text { trend / situation }\end{array}$ \\
\hline $\begin{array}{l}\text { Favourable } \\
(+)\end{array}$ & + & $\begin{array}{l}\text { Sufficient } \\
(+)\end{array}$ & $=$ & High $(++)$ \\
\hline $\begin{array}{l}\text { Favourable } \\
(+)\end{array}$ & + & $\begin{array}{l}\text { Insufficient } \\
(-)\end{array}$ & $=$ & Low (+ -) \\
\hline $\begin{array}{l}\text { Unfavourable } \\
(-)\end{array}$ & + & $\begin{array}{l}\text { Sufficient } \\
(+)\end{array}$ & $=$ & Low $(-+)$ \\
\hline $\begin{array}{l}\text { Unfavourable } \\
(-)\end{array}$ & + & $\begin{array}{l}\text { Insufficient } \\
(-)\end{array}$ & $=$ & Little (- -) \\
\hline
\end{tabular}

The social conditions, which is the outcome of both the social and the psychological factors, and the economic conditions (i.e., the infrastructure and institutional factors) jointly determine the extent of entrepreneurial behavior for a particular region. This has been set out systematically in the positive and negative matching exhibited in the above table. The existence of favorable social conditions and sufficient economic conditions jointly produces high possibility of entrepreneurial situation. On the other hand, the paucity of both of the conditions result in a very little scope for an entrepreneurial behavior. There is low possibility of occurring an entrepreneurial activity when the presence of one of the two conditions is either unfavorable or insufficient.

Entrepreneurship development is highly complicated process and subjected to certain socio-economic conditions prevailing in an economy. There is no one universal set of conditions conducive to entrepreneurial development. The personality traits and the socioeconomic conditions can be viewed, for simplicity of understanding, as the ones influencing the entrepreneurial activity to take place, in terms of factors that push or pull an individual into undertaking an entrepreneurial activity.

Push factors mean those influences, which push individuals into undertaking entrepreneurial activity. Pull factors mean influences, which pull people towards entrepreneurial phenomenon. The same influence can become a push factor for one individual but may be a pull factor for another. Unemployment is one example of that.

\section{SIgNIFICANCE OF THE STUDY}

Rajshahi, located on the northern bank of the Padma River, is one of the largest metropolitan cities in Bangladesh. It is a most important urban, commercial and educational city of North Bengal. It is also historically famous for silk production. It is comprised of 4 thanas with an average population density of 4068 per Sq. km. (BPC, 2001)

This city abodes the divisional head quarter of the Rajshahi Division. There are two public universities, two private universities, a public medical college and three private medical colleges besides many other educational institutions including technical and vocational ones. Necessary process for establishing a medical university and Bangladesh Krira Shikkha Protishthan is under way (Green Watch, Dhaka, 13th March 2018).

There is a textile mills, 6 handloom factories located in the city employing 791 persons. Besides these there are 199 handy crafts and 53 husking crafts mills located in the City Corporation (BBS, 2013).

Following table shows Number of establishment and person engaged in cottage industry (BBS, 2013, p.61).

\begin{tabular}{cccc} 
Number of units & \multicolumn{3}{c}{ Persons engaged } \\
\cline { 2 - 4 } 261 & Family & Hired & Total \\
\hline & 277 & 823 & 1100
\end{tabular}

A portrait of different industries in city corporation with number of employees engaged in those industries in the year of 2011 are given below (BBS, 2013, pp.59-69):

\begin{tabular}{|c|c|c|c|c|}
\hline \multirow[b]{2}{*}{ Category of industry } & \multicolumn{4}{|c|}{ No. of Persons engaged } \\
\hline & $\begin{array}{l}\text { Number } \\
\text { of units }\end{array}$ & $\begin{array}{l}\text { Family } \\
\text { members }\end{array}$ & Hired & Total \\
\hline $\begin{array}{l}\text { Number of bamboo and } \\
\text { cane industry and person } \\
\text { engaged }\end{array}$ & 23 & 11 & 127 & 138 \\
\hline $\begin{array}{llr}\begin{array}{l}\text { Number } \\
\text { furniture } \\
\text { engaged }\end{array} & \text { and } & \text { wooden } \\
\text { person }\end{array}$ & 128 & 88 & 512 & 600 \\
\hline $\begin{array}{l}\text { Number of Saw mill and } \\
\text { person engaged }\end{array}$ & 61 & 92 & 305 & 397 \\
\hline $\begin{array}{l}\text { Number of auto rice mill } \\
\text { and person engaged }\end{array}$ & 1 & 32 & 18 & 50 \\
\hline $\begin{array}{l}\text { Number of rice mill and } \\
\text { person engaged }\end{array}$ & 18 & 36 & 54 & 90 \\
\hline
\end{tabular}


Number of oil mills and

11

person engaged

person engaged

Number of printing press

and person engaged

Number of tailoring shop

and person engaged

Number of garments factory

(for local use) and person

engaged

Number of flour mill and person engaged

Number of plastic industry

and person engaged

Rajshahi and its neighboring areas are especially suitable for cultivation of various crops such as Mango, Lichi, Sugarcane, Potato, Tomato \& Watermelon. Though it is the fifth largest city in Bangladesh and located on a riverbank, industrial development in Rajshahi has not taken place to an extent it was supposed to be. There is an Industrial estate in Rajshahi, which is now mainly home to industries producing products of the famous Rajshahi silk. Head office of regulatory board for Sericulture, Bangladesh Sericulture Development Board also based in the city. Rajshahi is also a home to numbers of jute, textile and sugar mills, pharmaceutical and mango-based industries. Two $50 \mathrm{MW}$ power plants have already been built at Katakhali to meet the growing electricity demand of the city (Wikipedia, Retrieved on 13.03.2018).

In Bangladesh the unemployment rate is 4.2 with a male unemployment rate of 3.0 and a female unemployment rate of 6.8. Of the total Unemployed 2.6 million, among which 1.3 million males and 1.3 million females are unemployed (Statistical Year Book Bangladesh, 2016). Though Bangladesh has been witnessing the GDP growth rates over the last couple of years hovering around seven percent. A Govt. survey finds employment scenario nearly unchanged since 2013 (The Daily Star, May 28, 2017), which is alarming and the economy is witnessing jobless growth since 2013, such unemployment problem may turn into serious social problem producing social unrest and anarchy. Nearly a third of Bangladesh population comprise young people, aged between 10 and 24 years (Haque, 2017). To take advantage of this huge demographic potential, policymakers of the country need to make proper policy decision to create an environment friendly, equipped with effective support services, for this huge young portion of the people to propel the growth. In spite of being one of the fifth largest city in Bangladesh, the Rajshahi city is still very sluggish in achieving its economic pace. This study is an attempt to assess the influence of the push and full factors that give rise to entrepreneurial phenomena, and it is made to provide the policymaker with the necessary clues as to the reasons for entrepreneurial activities taking place within the study area.

\section{OBJectives OF THE Study}

The study has been conducted in line with the following objectives.

- To examine the impact of factors pushing individuals into undertaking entrepreneurial activities.

- $\quad$ To examine the impact of factors puling individuals towards undertaking entrepreneurial activities.

\section{Methodology of the Study}

This study is empirical in nature. Both primary and secondary data have been used for the study purpose. To collect primary data a questionnaire, containing 9 (nine) pull factors and 5 (five) push factors, was used. Primary data were collected from 50 respondents picked up purposively from among the individuals engaged in various entrepreneurial activities. The profiles of the respondents are shown in the following table.

Table 1: Pull and Push Factors used in the questionnaire.

\begin{tabular}{|c|c|c|c|}
\hline \multicolumn{2}{|r|}{ Pull factors } & \multicolumn{2}{|r|}{ Push factors } \\
\hline 1. & $\begin{array}{l}\text { Earning extra money for } \\
\text { family }\end{array}$ & 10. & $\begin{array}{l}\text { Lack of higher formal } \\
\text { education }\end{array}$ \\
\hline 2. & Family business tradition & 11. & $\begin{array}{l}\text { Curse of } \\
\text { unemployment }\end{array}$ \\
\hline 3. & $\begin{array}{l}\text { Gaining higher social } \\
\text { status }\end{array}$ & 12. & $\begin{array}{l}\text { Dissatisfaction with } \\
\text { previous occupation }\end{array}$ \\
\hline 4. & $\begin{array}{ll}\text { Self-employment with } \\
\text { economic freedom }\end{array}$ & 13. & $\begin{array}{l}\text { Family hardship and } \\
\text { pressure }\end{array}$ \\
\hline 5. & For inheritance case & 14. & Others \\
\hline 6. & $\begin{array}{l}\text { Use of personal knowledge } \\
\text { and experience }\end{array}$ & & \\
\hline 7. & $\begin{array}{l}\text { Less complex and more } \\
\text { profitable. }\end{array}$ & & \\
\hline 8. & $\begin{array}{l}\text { Support from the } \\
\text { government }\end{array}$ & & \\
\hline 9. & $\begin{array}{l}\text { Financial support from } \\
\text { the bank }\end{array}$ & & \\
\hline
\end{tabular}

Table 2: Profiles of the respondents

\begin{tabular}{|l|l|c|c|}
\hline Characteristics & Category & Frequency & Percentage \\
\hline Gender & Male & 46 & 92 \\
\cline { 2 - 4 } & Female & 4 & 8 \\
\cline { 2 - 4 } & Total & 50 & 100 \\
\hline Age in years & Below 30 & 14 & 28 \\
\cline { 2 - 4 } & $31-40$ & 18 & 36 \\
\cline { 2 - 4 } & 41 and above & 18 & 36 \\
\cline { 2 - 4 } & Total & 50 & 100 \\
\hline Edualifications & Below SSC & 20 & 40 \\
\cline { 2 - 4 } & SSC & 10 & 20 \\
\cline { 2 - 4 } & HSC & 6 & 12 \\
\cline { 2 - 4 } & $\begin{array}{l}\text { Graduation \& } \\
\text { above }\end{array}$ & 14 & 28 \\
\cline { 2 - 4 } & Total & 50 & 100 \\
\hline
\end{tabular}




\begin{tabular}{|l|l|c|c|}
\hline Ownership style & $\begin{array}{l}\text { Sole } \\
\text { Proprietorship }\end{array}$ & 44 & 88 \\
\cline { 2 - 4 } & Partnership & 4 & 8 \\
\cline { 2 - 4 } & $\begin{array}{l}\text { Private Ltd. } \\
\text { Company }\end{array}$ & 2 & 4 \\
\cline { 2 - 4 } & Total & 50 & 100 \\
\hline \multirow{5}{*}{ Experience } & $\begin{array}{l}\text { Without } \\
\text { experience }\end{array}$ & 26 & 52 \\
\cline { 2 - 4 } & Below 10 years & 12 & 24 \\
\cline { 2 - 4 } & $\begin{array}{l}10 \text { years and } \\
\text { above }\end{array}$ & 12 & 24 \\
\cline { 2 - 4 } enterprise & Total & 50 & 100 \\
\hline \multirow{5}{*}{ of } & Service & 20 & 40 \\
\cline { 2 - 4 } & Trading & 28 & 56 \\
\cline { 2 - 4 } & $\begin{array}{l}\text { Manufacturing } \\
\text { / real estate }\end{array}$ & 2 & 4 \\
\cline { 2 - 4 } & Total & 50 & 100 \\
\hline
\end{tabular}

\section{Data Analysis and Results}

The respondents were requested to put in their reactions about the push and pull factors on a five-point scale, ranging from strongly disagree (1) to strongly agree (5), as they perceive them to have important bearing on their taking entrepreneurial activities. Furthermore, the greater the agreement a respondent find with the statement the larger the quantity he or she was requested to assign against each of the statements.

Table 3: Ranks of the pull factors as perceived by the respondents.

\begin{tabular}{|c|c|c|c|c|}
\hline \multicolumn{2}{|c|}{ Pull factors } & Average & Rank & SD \\
\hline 1. & $\begin{array}{l}\text { Earning extra money for } \\
\text { family }\end{array}$ & 4.52 & 1 & 0.59 \\
\hline 2. & Family business tradition & 3.24 & 4 & 1.16 \\
\hline 3. & Gaining higher social status & 3.2 & 5 & 1.29 \\
\hline 4. & $\begin{array}{ll}\begin{array}{l}\text { Self-employment } \\
\text { economic freedom }\end{array} & \text { with } \\
\end{array}$ & 4.36 & 2 & 0.91 \\
\hline 5. & For inheritance cause & 2.72 & 7 & 1.37 \\
\hline 6. & $\begin{array}{l}\text { Use of personal knowledge } \\
\text { and experience }\end{array}$ & 3.96 & 3 & 1.24 \\
\hline 7. & $\begin{array}{l}\text { Less complex and more } \\
\text { profitable. }\end{array}$ & 4.36 & 2 & 0.70 \\
\hline 8. & Support from the government & 2.21 & 6 & 0.59 \\
\hline 9. & $\begin{array}{l}\text { Financial support from the } \\
\text { bank }\end{array}$ & 1.8 & 7 & 0.67 \\
\hline
\end{tabular}

From the table -3 , it is seen that the pull factor "earning extra money for family" has been ranked in the first place and both the factors such as "self-employment with economic freedom" and "Less complex and more profitable" have placed in the second position, followed by the factor "Use of personal knowledge and experience" being at the third position. The pull factors "For inheritance case" and "Financial support from the bank" have been placed in the lowest rank that is $7^{\text {th }}$ position. The second lowest position has been occupied by the factor "support from the bank"
Table 4: Ranks of the push factors as perceived by the respondents

\begin{tabular}{|c|c|c|c|c|}
\hline \multicolumn{2}{|c|}{ Push factors } & Average & Rank & SD \\
\hline 10. & $\begin{array}{l}\text { Lack of higher formal } \\
\text { education }\end{array}$ & 2.64 & 3 & 1.38 \\
\hline 11. & Curse of unemployment & 3.08 & 1 & 1.55 \\
\hline 12. & $\begin{array}{l}\text { Dissatisfaction with previous } \\
\text { occupation }\end{array}$ & 2.04 & 5 & 1.17 \\
\hline 13. & $\begin{array}{lll}\begin{array}{l}\text { Family } \\
\text { pressure }\end{array} & & \\
\end{array}$ & 2.6 & 4 & 1.41 \\
\hline 14. & Others & 2.7 & 2 & 1.16 \\
\hline
\end{tabular}

The table 4 reveals that push factor "curse of unemployment" has been ranked in the 1st position and other factors have been ranked in the second position followed by "Lack of higher formal education" being ranked in the third position. "Dissatisfaction with previous occupation" has been ranked in the lowest position.

Table 5: Ranks of the pull factors as perceived by the respondents according to differences in gender

\begin{tabular}{|c|c|c|c|c|c|c|c|}
\hline \multirow{2}{*}{\multicolumn{2}{|c|}{ Characteristics }} & \multicolumn{6}{|c|}{ Gender } \\
\hline & & \multicolumn{3}{|c|}{ Male } & \multicolumn{3}{|c|}{ Female } \\
\hline \multicolumn{2}{|c|}{ Pull factors } & 0 & & & 0 & & \\
\hline 1. & $\begin{array}{l}\text { Earning extra } \\
\text { money for family }\end{array}$ & 4.52 & 1 & 0.60 & 4.50 & 2 & 0.58 \\
\hline 2. & $\begin{array}{l}\text { Family business } \\
\text { tradition }\end{array}$ & 3.43 & 5 & 1.11 & 3.05 & 6 & 1.21 \\
\hline 3. & $\begin{array}{l}\text { Gaining higher } \\
\text { social status }\end{array}$ & 3.04 & 6 & 1.12 & 3.36 & 5 & 1.46 \\
\hline 4. & $\begin{array}{l}\text { Self-employment } \\
\text { with economic } \\
\text { freedom }\end{array}$ & 4.34 & 2 & 0.93 & 4.38 & 3 & 0.93 \\
\hline 5. & $\begin{array}{l}\text { For inheritance } \\
\text { Cause }\end{array}$ & 2.95 & 7 & 1.26 & 2.49 & 7 & 1.48 \\
\hline 6. & $\begin{array}{lr}\text { Use of personal } \\
\text { knowledge } \\
\text { experience }\end{array}$ & 3.78 & 3 & 1.24 & 4.14 & 4 & 1.24 \\
\hline 7. & $\begin{array}{l}\text { Less complex and } \\
\text { more profitable. }\end{array}$ & 3.65 & 4 & 0.70 & 5.07 & 1 & 0.70 \\
\hline 8. & $\begin{array}{l}\text { Support from the } \\
\text { government }\end{array}$ & 2.40 & 8 & 0.57 & 2.02 & 8 & 0.61 \\
\hline 9. & $\begin{array}{l}\text { Financial support } \\
\text { from the bank }\end{array}$ & 1.82 & 9 & 0.68 & 1.78 & 9 & 0.66 \\
\hline
\end{tabular}

The table 5 depicts the ranks of different pull factors according to the genders of the respondents. The male respondents have placed the factors 'Earning extra money for family' and 'Self-employment with economic freedom in the $1^{\text {st }}$ and $2^{\text {nd }}$ positions respectively. Whereas female respondents have perceived the factors, 'Less complex and more profitable' and 'Earning extra money for family 'to be the most important and second most important respectively. The 'support from the government' and 'the 'financial support from the bank' have been found to be little to do with the respondents' undertaking entrepreneurial activity. 
Table 6: Ranks of the pull factors as perceived by the respondents according to differences in age

\begin{tabular}{|c|c|c|c|c|c|c|c|c|c|c|}
\hline \multirow{3}{*}{\multicolumn{2}{|c|}{$\begin{array}{l}\text { Characteristics } \\
\text { Pull factors }\end{array}$}} & \multicolumn{9}{|c|}{ Age in years } \\
\hline & & \multicolumn{3}{|c|}{ Below 30} & \multicolumn{3}{|c|}{$31-40$} & \multicolumn{3}{|c|}{41 and above } \\
\hline & & 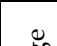 & & & & & & \& & & \\
\hline 1 . & $\begin{array}{l}\text { Earning extra } \\
\text { money for family }\end{array}$ & 4.49 & 1 & 0.58 & 4.50 & 1 & 0.59 & 4.57 & 1 & 0.60 \\
\hline 2. & $\begin{array}{l}\text { Family business } \\
\text { tradition }\end{array}$ & 3.22 & 5 & 1.10 & 3.24 & 5 & 1.15 & 3.26 & 5 & 1.23 \\
\hline 3 & $\begin{array}{l}\text { Gaining higher } \\
\text { social status }\end{array}$ & 3.20 & 6 & 1.25 & 3.21 & 6 & 1.28 & 3.19 & 6 & 1.34 \\
\hline 4 & $\begin{array}{l}\text { Self-employment } \\
\text { with economic } \\
\text { freedom }\end{array}$ & 4.30 & 3 & 0.92 & 4.38 & 2 & 0.93 & 4.40 & 2 & 0.88 \\
\hline 5 . & $\begin{array}{l}\text { For inheritance } \\
\text { cause }\end{array}$ & 2.72 & 7 & 1.38 & 2.73 & 7 & 1.36 & 2.71 & 7 & 1.37 \\
\hline
\end{tabular}

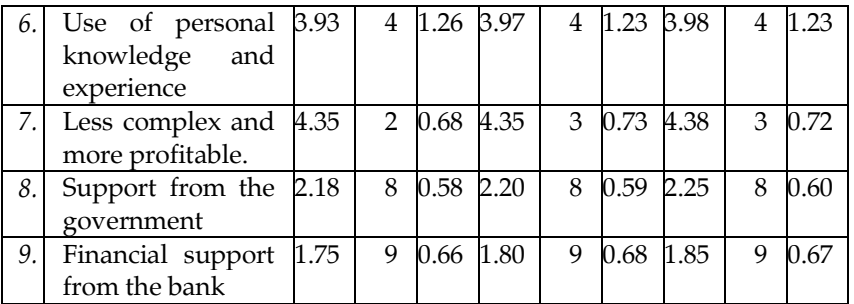

The table 6 showing the ranks of pull factors as perceived by the respondents according to their age. The table reveals that irrespective of differences in their ages the factors 'Earning extra money for family' and 'Selfemployment with economic freedom' have been placed in the 1st and 2nd positions respectively. Again, it can be come across from the table that support from the government and financial institutions have been placed in the lowest ranks.

Table 7: Ranks of the pull factors as perceived by the respondents according to differences in educational qualifications

\begin{tabular}{|c|c|c|c|c|c|c|c|c|c|c|c|c|c|}
\hline \multirow{3}{*}{\multicolumn{2}{|c|}{$\begin{array}{l}\text { Characteristics } \\
\text { Pull factors }\end{array}$}} & \multicolumn{12}{|c|}{ Educational qualifications } \\
\hline & & \multicolumn{3}{|c|}{ Below SSC } & \multicolumn{3}{|c|}{ SSC } & \multicolumn{3}{|c|}{ HSC } & \multicolumn{3}{|c|}{ Graduation \& above } \\
\hline & & $\Phi$ & & & $\ddot{\infty}$ & & & 8 & & & $\ddot{\infty}$ & & \\
\hline 1. & Earning extra money for family & 4.50 & 2 & 0.53 & 4.00 & 3 & 0.71 & 4.67 & 2 & 0.58 & 4.91 & 2 & 0.58 \\
\hline 2. & Family business tradition & 3.10 & 5 & 1.05 & 3.00 & 5 & 1.58 & 3.67 & 4 & 0.58 & 3.19 & 5 & 1.43 \\
\hline 3. & Gaining higher social status & 3.00 & 6 & 1.45 & 3.20 & 4 & 1.79 & 2.33 & & 1.53 & 4.27 & 3 & 0.39 \\
\hline 4. & Self-employment with economic freedom & 4.70 & 1 & 0.48 & 4.80 & 1 & 0.45 & 5.00 & 1 & 0.52 & 2.94 & 6 & 2.19 \\
\hline 5. & For inheritance cause & 2.90 & 7 & 1.79 & 2.40 & & 1.34 & 3.67 & 4 & 1.15 & 1.91 & 8 & 1.20 \\
\hline 6. & Use of personal knowledge and experience & 3.30 & 4 & 1.49 & 4.00 & 3 & 1.50 & 4.33 & 3 & 1.85 & 4.21 & 4 & 0.12 \\
\hline 7. & Less complex and more profitable. & 3.40 & 3 & 1.58 & 4.20 & 2 & .84 & 2.67 & 5 & 1.15 & 7.17 & 1 & 0.23 \\
\hline 8. & Support from the government & 2.01 & 8 & 0.54 & 2.00 & 6 & 0.57 & 2.2 & 6 & 0.51 & 2.63 & 7 & 0.74 \\
\hline & Financial support from the bank & 1.70 & 9 & 0.65 & 1.80 & 7 & 0.67 & 1.9 & 7 & 0.62 & 1.80 & 9 & 0.74 \\
\hline
\end{tabular}

Table 7 presents the ranks of the pull factors as perceived by the respondents according to their differences in educational qualifications. Irrespective of differences in educational qualifications the respondents have placed the factor 'Earning extra money for family' in the second position. Both the respondents with HSC degree and below HSC have placed the factor 'Self-employment with economic freedom' in the first position. The respondents with graduation and above graduation degrees have ranked the factor 'Less complex and more profitable' in the first position. Irrespective of their varied qualifications the respondents have placed the 'support from the government' and 'support from financial institutions' in the lowest ranks perceiving their meagre roles in triggering any entrepreneurial phenomenon.

Table 8: Ranks of the pull factors as perceived by the respondents according to differences in ownership style

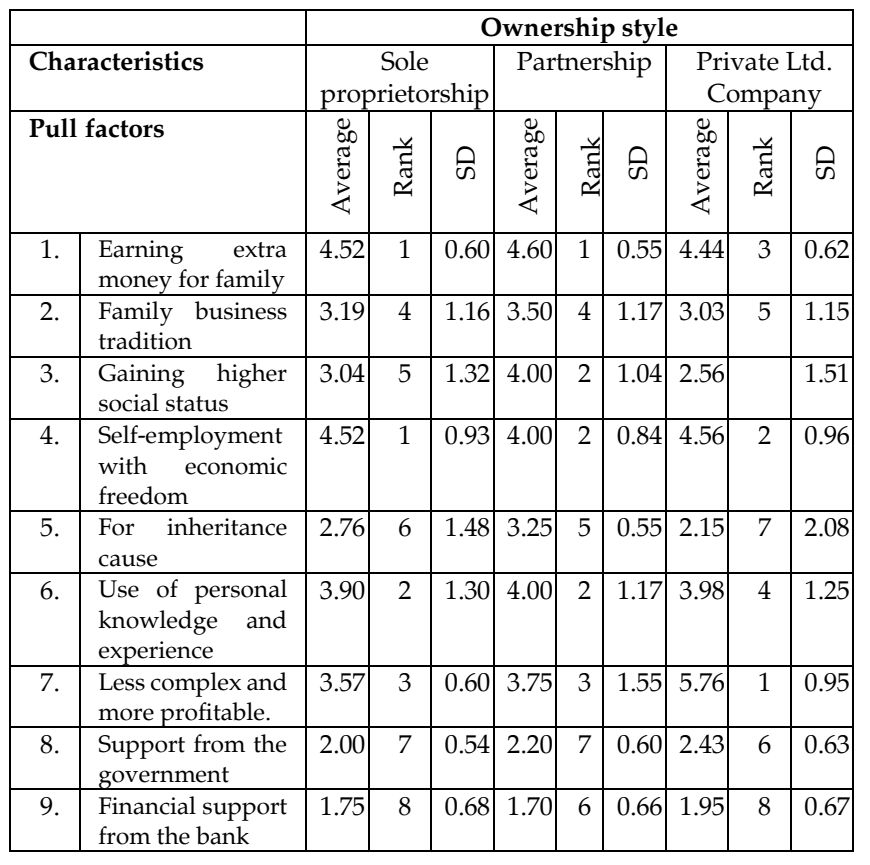


Table- 8 exhibits the ranks of the pull factors as perceived by the respondents according to differences in ownership style. The respondents engaged in sole proprietorship and partnership businesses have placed the factor 'Earning extra money for family' in the first position and 'Use of personal knowledge and experience', in the second position. Whereas, respondents engaged in private company business placed the factor 'Less complex and more profitable' in the first rank and 'Self-employment with economic freedom' in the second position. Again, supports from the government and financial institutions have been found to have least role in generating entrepreneurial phenomena.

Table 9: Ranks of the pull factors as perceived by the respondents according to differences in their experiences.

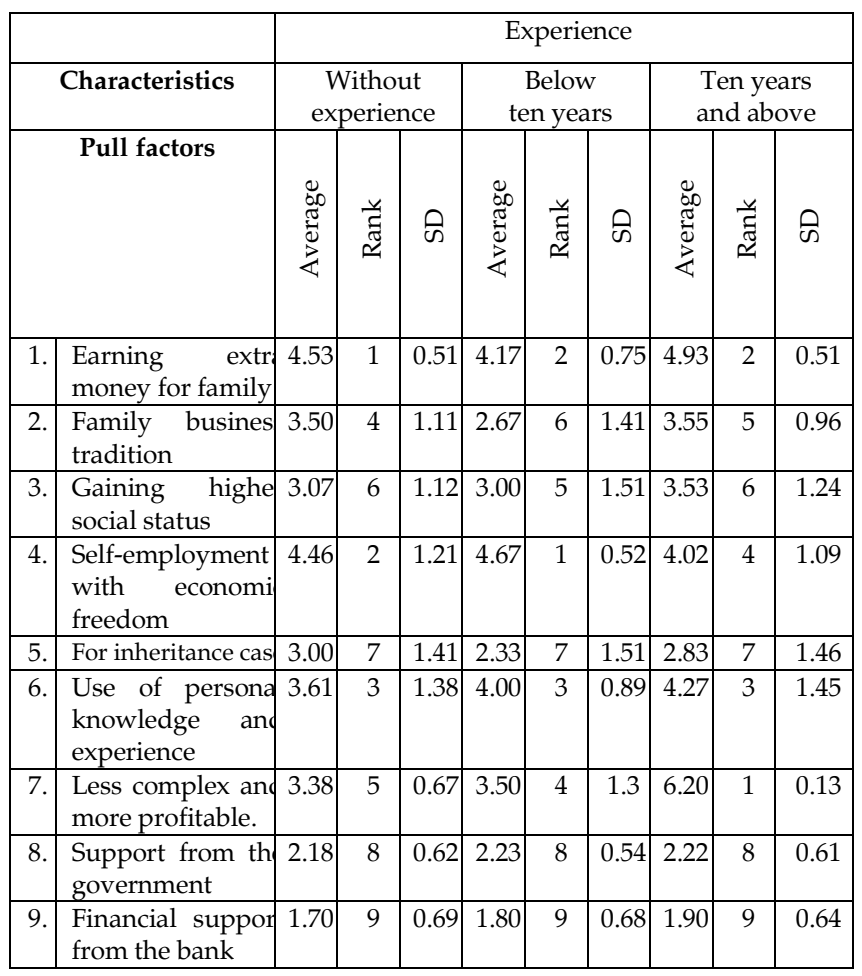

Table 9 reveals the ranks of the pull factors as perceived by the respondents according to differences in their experiences. The table exhibits that the respondents with experience of 10 years and above have ranked the factors 'Less complex and more profitable' and 'Earning extra money for family' in the first and second positions respectively, whereas the respondents without any experience and with experience below ten years have ranked the factors 'Earning extra money for family' and 'Self-employment with economic freedom' in the first or second place contrariwise. Irrespective of differences in experiences the factor 'Use of personal knowledge and experience' has been ranked in the third place.
Table 10: Ranks of the pull factors as perceived by the respondents according to differences in the nature of enterprises

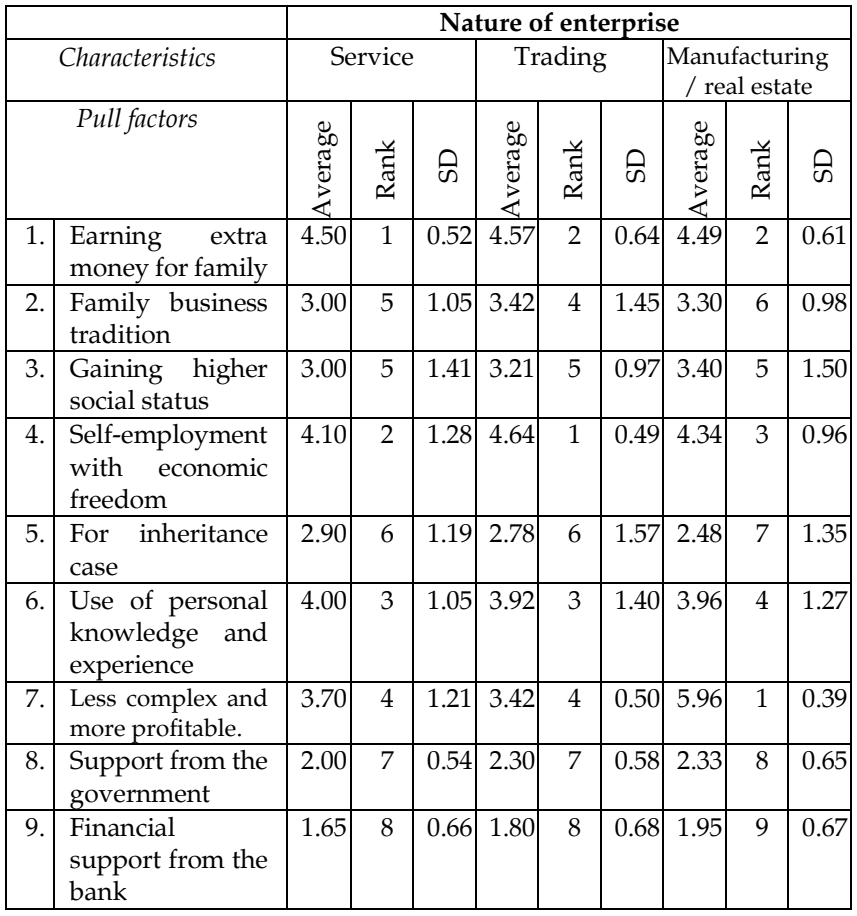

Table 10 displays the ranks of the pull factors as perceived by the respondents according to differences in the nature of enterprises. The respondents in the service sector have placed the factors 'Earning extra money for family' and 'Self-employment with economic freedom' in the first and second ranks respectively. On the other hand, the respondents engaged in the trading business have ranked the same conversely, i.e., 'Self-employment with economic freedom' in the first position and 'Earning extra money for family' in the second position. The respondents engaged in the Manufacturing / real estate businesses ranked 'Less complex and more profitable' in the first place and 'Earning extra money for family' in the second place. In all the cases it is obvious from the table that support from the government and financial institution played least role in forcing them into undertaking the entrepreneurial role.

Table 11: Ranks of the push factors as perceived by the respondents according to differences in their genders

\begin{tabular}{|c|c|c|c|c|c|c|c|}
\hline \multicolumn{2}{|r|}{ Characteristics } & \multicolumn{6}{|c|}{ Gender } \\
\hline & & \multicolumn{3}{|c|}{ Male } & \multicolumn{3}{|c|}{ Female } \\
\hline \multicolumn{2}{|r|}{ Push factors } & $\underset{\sigma}{\infty}$ & $\exists$ & & $\underset{\sigma}{8}$ & & \\
\hline 10. & Lack of higher formal education & 2.69 & 3 & 1.39 & 2.59 & 4 & 1.37 \\
\hline 11. & Curse of unemployment & 2.95 & 1 & 1.85 & 3.21 & 1 & 1.25 \\
\hline 12. & $\begin{array}{l}\text { Dissatisfaction with previous } \\
\text { occupation }\end{array}$ & 1.91 & 5 & 1.04 & 2.17 & 5 & 1.30 \\
\hline 13. & Family hardship and pressure & 2.52 & 4 & 1.44 & 2.68 & 2 & 1.38 \\
\hline 14. & Others & 2.73 & 2 & 1.21 & 2.67 & 3 & 1.11 \\
\hline
\end{tabular}


Table 11 shows the ranks of the push factors as perceived by the respondents according to differences in their genders. It can be seen from the table that for both the male and female entrepreneurs under study 'curse of unemployment' has stood as the most important factor forcing them to undertake the entrepreneurial activity. For female entrepreneurs under study 'Family hardship and pressure' has been found to be second most important motivating factor forcing them toward undertaking the entrepreneurial activity.

Table 12: Ranks of the push factors as perceived by the respondents according to differences in their ages

\begin{tabular}{|c|c|c|c|c|c|c|c|c|c|c|}
\hline \multicolumn{2}{|r|}{ Characteristics } & \multicolumn{9}{|c|}{ Age in years } \\
\hline & & \multicolumn{3}{|c|}{ Below 30} & \multicolumn{3}{|c|}{$31-40$} & \multicolumn{3}{|c|}{41 and above } \\
\hline \multicolumn{2}{|r|}{ Push factors } & 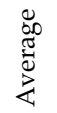 & 䒕 & कि & 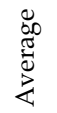 & $\begin{array}{l}\text { है } \\
\text { Е }\end{array}$ & कि & 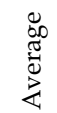 & है & कि \\
\hline 10. & $\begin{array}{l}\text { Lack of higher } \\
\text { formal } \\
\text { education }\end{array}$ & 2.60 & 3 & 1.48 & 2.80 & 3 & 1.30 & 2.52 & 4 & 1.36 \\
\hline 11. & $\begin{array}{l}\text { Curse of } \\
\text { unemployment }\end{array}$ & 3.00 & 1 & 1.64 & 3.20 & 1 & 1.58 & 3.04 & 1 & 1.43 \\
\hline 12. & $\begin{array}{l}\text { Dissatisfaction } \\
\text { with previous } \\
\text { occupation }\end{array}$ & 2.10 & 5 & 1.18 & 2.40 & 5 & 1.08 & 1.62 & 5 & 1.25 \\
\hline 13. & $\begin{array}{l}\text { Family hardship } \\
\text { and pressure }\end{array}$ & 2.40 & 4 & 1.67 & 2.67 & 4 & 1.52 & 2.73 & 2 & 1.04 \\
\hline 14. & Others & 2.63 & 2 & 1.20 & 2.83 & 2 & 1.30 & 2.64 & 3 & 0.98 \\
\hline
\end{tabular}

From the table 12, it is seen that all the respondents' irrespective differences in their ages have ranked the factor 'Curse of unemployment' in the first position.

Table 13: Ranks of the push factors as perceived by the respondents according to differences in their educational qualification

\begin{tabular}{|c|c|c|c|c|c|c|c|c|c|c|c|c|c|}
\hline \multicolumn{2}{|r|}{ Characteristics } & \multicolumn{12}{|c|}{ Educational qualifications } \\
\hline & & \multicolumn{3}{|c|}{ Below SSC } & \multicolumn{3}{|c|}{ SSC } & \multicolumn{3}{|c|}{ HSC } & \multicolumn{3}{|c|}{$\begin{array}{c}\text { Graduation } \\
\& \text { above }\end{array}$} \\
\hline \multicolumn{2}{|r|}{ Push factors } & 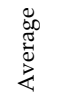 & है & के & 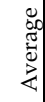 & $\begin{array}{l}\text { चี } \\
\text { ๕ }\end{array}$ & क & 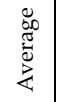 & 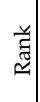 & की & 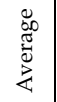 & 究 & के \\
\hline 10. & $\begin{array}{l}\text { Lack of } \\
\text { higher formal } \\
\text { education }\end{array}$ & 3.50 & 2 & 0.71 & 2.60 & 4 & 2.14 & 2.33 & 3 & 1.15 & 2.13 & 1 & 1.52 \\
\hline 11. & $\begin{array}{l}\text { Curse of } \\
\text { unemployment }\end{array}$ & 3.90 & 1 & 1.10 & 3.60 & 1 & 2.23 & 3.67 & 1 & 1.53 & 1.15 & 5 & 1.34 \\
\hline 12. & $\begin{array}{l}\text { Dissatisfaction } \\
\text { with previous } \\
\text { occupation }\end{array}$ & 2.00 & 5 & 1.25 & 3.00 & 3 & 1.41 & 2.00 & 4 & 1.10 & 1.16 & 4 & 0.92 \\
\hline 13. & $\begin{array}{l}\text { Family } \\
\text { hardship and } \\
\text { pressure }\end{array}$ & 3.30 & 3 & 2.23 & 3.20 & 2 & 2.23 & 2.00 & 4 & 1.00 & 1.9 & 2 & 1.57 \\
\hline 14. & Others & 3.00 & 4 & 0.94 & 3.60 & 1 & 1.14 & 2.67 & 2 & 1.53 & 1.53 & 3 & 1.03 \\
\hline
\end{tabular}

The Table 13 shows the ranks of the push factors as perceived by the respondents according to differences in their educational qualification. It can be seen from the table that the factor 'Curse of unemployment' has appeared as the most important factor motivating them toward undertaking the entrepreneurial activity.
Table 14: Ranks of the push factors as perceived by the respondents according to differences in ownership

\begin{tabular}{|c|c|c|c|c|c|c|c|c|c|c|}
\hline \multicolumn{2}{|r|}{ Characteristics } & \multicolumn{9}{|c|}{ Ownership style } \\
\hline & & \multicolumn{3}{|c|}{$\begin{array}{c}\text { Sole } \\
\text { proprietorship }\end{array}$} & \multicolumn{3}{|c|}{ Partnership } & \multicolumn{3}{|c|}{$\begin{array}{c}\text { Private Ltd. } \\
\text { Company }\end{array}$} \\
\hline & Push factors & 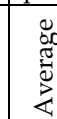 & שี & कि & 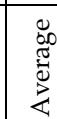 & 䒕 & कि & 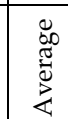 & 䒕 & कि \\
\hline 10. & $\begin{array}{l}\text { Lack of higher } \\
\text { formal education }\end{array}$ & 2.67 & 4 & 1.32 & 1.50 & 4 & 1.91 & 3.75 & 2 & 0.91 \\
\hline 11. & $\begin{array}{l}\text { Curse of } \\
\text { unemployment }\end{array}$ & 3.33 & 1 & 1.46 & 1.75 & 2 & 1.50 & 4.16 & 1 & 1.69 \\
\hline 12. & $\begin{array}{l}\text { Dissatisfaction } \\
\text { with previous } \\
\text { occupation }\end{array}$ & 2.10 & 5 & 1.21 & 1.25 & 3 & 0.50 & 2.77 & 5 & 1.80 \\
\hline 13. & $\begin{array}{l}\text { Family hardship } \\
\text { and pressure }\end{array}$ & 2.86 & 2 & 1.39 & 1.25 & 3 & 1.68 & 3.69 & 3 & 1.16 \\
\hline 14. & Others & 2.81 & 3 & 1.08 & 2.50 & 1 & 1.75 & 2.79 & 4 & 0.65 \\
\hline
\end{tabular}

Table 14 exhibits the ranks of the push factors as perceived by the respondents according to differences in ownership. The respondents engaged in sole proprietorship business placed 'curse of unemployment' in the first position and 'Family hardship and pressure' in the second position. On the other hand, the respondents in the partnership business placed the factor 'curse on unemployment' in the second position, and the respondents in private ltd. company businesses have ranked 'Curse of unemployment' in the first place and 'Lack of higher formal education' in the second position.

Table 15: Ranks of the push factors as perceived by the respondents according to differences in their experience

\begin{tabular}{|c|c|c|c|c|c|c|c|c|c|c|}
\hline \multirow{2}{*}{\multicolumn{2}{|c|}{ Characteristics }} & \multicolumn{9}{|c|}{ Experience } \\
\hline & & \multicolumn{3}{|c|}{$\begin{array}{c}\text { Without } \\
\text { experience }\end{array}$} & \multicolumn{3}{|c|}{$\begin{array}{c}\text { Below } \\
\text { ten years }\end{array}$} & \multicolumn{3}{|c|}{$\begin{array}{c}\text { Ten years } \\
\text { and above }\end{array}$} \\
\hline & Push factors & 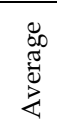 & है & के & 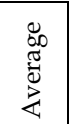 & 䒕 & $\theta$ & 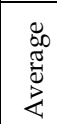 & 气 & कि \\
\hline 10 . & $\begin{array}{l}\text { Lack of higher } \\
\text { formal education }\end{array}$ & 2.62 & 4 & 1.33 & 3.33 & 3 & 1.03 & 1.97 & 3 & 1.78 \\
\hline 11. & $\begin{array}{lr}\text { Curse of } \\
\text { unemployment }\end{array}$ & 3.54 & 1 & 1.45 & 3.50 & 2 & 1.84 & 2.20 & 1 & 1.36 \\
\hline 12 . & $\begin{array}{l}\text { Dissatisfaction } \\
\text { with previous } \\
\text { occupation }\end{array}$ & 2.31 & 5 & 1.11 & 1.83 & 5 & 0.75 & 1.98 & 2 & 1.65 \\
\hline 13. & $\begin{array}{l}\text { Family hardship } \\
\text { and pressure }\end{array}$ & 2.77 & 2 & 1.48 & 2.83 & 4 & 1.47 & 2.20 & 1 & 1.28 \\
\hline 14. & Others & 2.69 & 3 & 1.03 & 3.83 & 1 & 0.75 & 1.58 & 4 & 1.7 \\
\hline
\end{tabular}

Table 15 reveals the ranks of the push factors as perceived by the respondents according to differences in their experiences. The respondents without experience have ranked 'Curse of unemployment' as the most important factor for coming up with entrepreneurial initiative followed by 'Family hardship and pressure'. On the other hand, entrepreneurs with experience of more than ten years have viewed both the factors equally important and place them in the first position. 
Table 16: Ranks of the push factors as perceived by the respondents according to differences in nature of businesses

\begin{tabular}{|c|c|c|c|c|c|c|c|c|c|c|}
\hline \multirow{2}{*}{\multicolumn{2}{|c|}{ Characteristics }} & \multicolumn{9}{|c|}{ Nature of business } \\
\hline & & \multicolumn{3}{|c|}{ Service } & \multicolumn{3}{|c|}{ Trading } & \multicolumn{3}{|c|}{$\begin{array}{c}\text { Manufacturing } \\
\text { / real estate }\end{array}$} \\
\hline & Push factors & 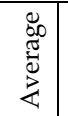 & $\begin{array}{l}\text { है } \\
\text { ๕్ }\end{array}$ & कि & 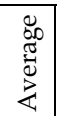 & 䒕 & क & 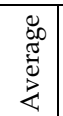 & 苂 & के \\
\hline 10. & $\begin{array}{l}\text { Lack of higher } \\
\text { formal education }\end{array}$ & 3.00 & 2 & 1.56 & 2.57 & 3 & 1.22 & 2.42 & 3 & 1.36 \\
\hline 11. & $\begin{array}{l}\text { Curse of } \\
\text { unemployment }\end{array}$ & 3.20 & 1 & 1.81 & 3.21 & 1 & 1.36 & 2.83 & 1 & 1.48 \\
\hline 12. & $\begin{array}{l}\text { Dissatisfaction } \\
\text { with previous } \\
\text { occupation }\end{array}$ & 2.30 & 4 & 1.25 & 1.78 & 5 & 1.12 & 2.04 & 5 & 1.05 \\
\hline 13. & $\begin{array}{l}\text { Family hardship } \\
\text { and pressure }\end{array}$ & 2.90 & 3 & 0.99 & 2.42 & 4 & 1.55 & 2.48 & 2 & 1.69 \\
\hline 14. & Others & 3.00 & 2 & 1.15 & 2.71 & 2 & 1.20 & 2.39 & 4 & 1.13 \\
\hline
\end{tabular}

Table 16 shows the rank of the push factors as perceived by the respondents according to their differences in nature of businesses. From the table it can be observed that irrespective of the nature of businesses, all the respondents have viewed the factor 'Curse of unemployment' as the most important factor that compelled them to undertake an entrepreneurial activity.

\section{CONCLUSION}

Entrepreneurial phenomenon is highly complicated and subjected to the influences of myriad of variables including socio-economic, political factors at large. There is no universal set of predetermined factors that can be assumed to explain the reasons for any entrepreneurial activity being taken place.

The pull factor "earning extra money for family" has appeared as the most important motivating factor for undertaking entrepreneurial activity. Both the factors such as "self-employment with economic freedom" and "Less complex and more profitable" have emerged as the second most important factors contributing to an entrepreneurial phenomenon, followed by the factor "Use of personal knowledge and experience" being the third most important factor.

The push factor "curse of unemployment" has been ranked in the $1^{\text {st }}$ position and 'other factors' have been ranked in the second position followed by "Lack of higher formal education" being ranked in the third position. "Dissatisfaction with previous occupation" has been ranked in the lowest position.

The male respondents placed the pull factors 'Earning extra money for family' and 'Self-employment with economic freedom' in the $1^{\text {st }}$ and $2^{\text {nd }}$ positions respectively. Whereas the female respondents have perceived the factors, 'Less complex and more profitable' and 'Earning extra money for family 'to be most important and second most important ones. The support from the government and the financial support from the bank have been found to be little to do with the respondents' undertaking the entrepreneurial activity.
Irrespective of differences in educational qualifications the respondents have viewed the pull factor 'Earning extra money for family' as second most important motivating factor. The respondents with HSC degree and below HSC have found the factor 'Self-employment with economic freedom' as the most important motivating factor. The respondents with graduation and above graduation degrees have regarded the factor 'Less complex and more profitable' as the most important motivating factor. Irrespective of their varied qualifications the respondents have viewed the support from the government and financial institutions as least important motivating factors.

The respondents engaged in sole proprietorship and partnership businesses have found the factor 'Earning extra money for family' as the most important motivating factor and 'Use of personal knowledge and experience', as the second most important motivating factor,

The respondents with experience of 10 years and above have ranked the factors 'Less complex and more profitable' and 'Earning extra money for family' as the most important and second most important motivating factors respectively. Whereas the respondents without and with experience below ten years have ranked the factors 'Earning extra money for family' and 'Selfemployment with economic freedom' in the first or second place contrariwise.

The respondents in the service sector have placed the factors 'Earning extra money for family' and 'Selfemployment with economic freedom' as the most important and second most important motivating factors. On the other hand, the respondents engaged in the trading business have ranked the same conversely, i.e., 'Selfemployment with economic freedom' as the most important motivating factor and 'Earning extra money for family' as second most important factor. The respondents engaged in the Manufacturing / real estate businesses ranked 'Less complex and more profitable' as the most important motivating factor and 'Earning extra money for family' as the second most important factor motivating them to undertake an entrepreneurial activity.

For both the male and female entrepreneurs 'curse of unemployment' has stood as the most important factor forcing them to undertake entrepreneurial activity. All the respondents' irrespective differences in their ages have found the factor 'Curse of unemployment' as the most important factor pushing them toward undertaking entrepreneurial activity.

The respondents engaged in sole proprietorship business placed 'curse of unemployment' in the first position. On the other hand, the respondents in the partnership business viewed the factor 'curse on unemployment' as the second most important factor, and the respondents in private ltd. company businesses have ranked 'Curse of unemployment' as most important push factor. 
The respondents without experience have ranked 'Curse of unemployment' as the most important factor for coming up with an entrepreneurial initiative followed by 'Family hardship and pressure'. On the other hand, entrepreneurs with experience of more than ten years have viewed both the factors equally important and viewed them as the most important factor.

Irrespective of the nature of businesses they are engaged in, all the respondents have viewed the factor 'Curse of unemployment' as the most important factor that compelled them to undertake entrepreneurial activity.

\section{REFERENCES}

Bangladesh Bureau of Statistics (BBS), District Statistics 2011 Rajshahi June 2013, Statistics and Informatics Division Ministry of Planning, Government of The People's Republic of Bangladesh, Published in June, 2013 Published by: Bangladesh Bureau of Statistics (BBS) Printed at: Reproduction, Documentation and Publication (RDP) Section, FA \& MIS, BBS, P.71.

Bangladesh Population Census (BPC) 2001, Bangladesh Bureau of Statistics; Cultural survey report of 2007; Field reports of Rajshahi City.

Cochran, C. F. (1965). "The Entrepreneur in Economic Change", "Explorations in Entrepreneurial History", VOL. 3 No. 1 pp.2537; also reprinted in Kilby, edited, The Free Press. pp.95-108.

Green Watch, Dhaka, Tuesday 13th March 2018, (Rajshahi economy based on education, ICT, health sectors: Liton, Daily People's Voice for Sustainable Life, Retrieved on 11.03.2018. http://greenwatchbd.com/rajshahi-economybased-on-education-ict-health-sectors-liton/).

Haque, A.N.M Nurul, 2017, Prevalence of Unemployment in Bangladesh, Daily Sun, 24 January, Retrieved on 11.03.2018, http:/ / www.daily-

sun.com/arcprint/details/200667/Prevalence-of-

Unemployment-in-Bangladesh/2017-01-24
Mahmud, A. A. (1974). "Developing Effective Indigenous Entrepreneurs, 1980, "Malaysian Management Review, Vol. 9, No. 1, P. 47. (also, Sharma, R.A. "Entrepreneurial Change in Indian History", Sterling Publishers Pvt. Ltd., New Delhi, India, P. 9).

Mishra, D. N. (1990). "Entrepreneurship - Its Development" in "Entrepreneurship Development in India", ed., Sami Uddin, at el, Mittal Publications, p. 187.

Praag, C. M. V. (1999). "Some Classic Views on Entrepreneurship" De Economist 147(3):311-335, Retrieved on 05.03.2018 https:/ / www.researchgate.net/publication/226397652_So me_Classic_Views_on_Entrepreneurship.

Sharma, R. A. (1980). "Entrepreneurial Change in Indian History", Sterling Publishers Pvt. Ltd., New Delhi, India, PP. 6-8.

Srivastava, A. K. (1989). "Developing Entrepreneurship: A strategy layout" in "Entrepreneurship: Reflections and Investigations", ed., Bisht N.S. et.al, Chug Publications, India, PP. 46-48.

Statistical Year Book Bangladesh, 2016, 36th edition published in May 2017 Bangladesh Bureau of Statistics, Statistics \& Informatics Division (SID), Ministry of Planning Government of The People's Republic of Bangladesh Dhaka, Bangladesh www.bbs.gov.bd, Page 71-72,

Stocks, R. G. (1974). “The Afrikaner industrial Entrepreneur and Afrikaner Nationalism", "Economic Development and Cultural Change", Vol.22, No. 4, PP. 557-559.

The Daily Star, May 28, 2017, 26 lakh jobless, retrieved on 11.03.2018 www.thedailystar.net/frontpage/26-lakhyouths-jobless- 1411804

Wikipedia, the free encyclopedia, Retrieved on 13.03.2018, https://en.wikipedia.org/wiki/Rajshahi 
